\title{
Geoecological evaluation of the territory in the GIS environment in the preparation of information for land management design
}

\author{
Aleksey Osipov ${ }^{1}$, Vladimir Bogdanov ${ }^{2}$, Vitaly Garmanov ${ }^{2}$, Viktoriia Pavlova ${ }^{2}$, Ekaterina \\ Uvarova $^{2}$, Kasim Layshev ${ }^{3}$, Aleksandr Nikonorov $^{4 *}$ and Luka Akimov ${ }^{4,5}$ \\ ${ }^{1}$ A.F. Mozhaysky's Military-Space Academy, Zhdanovskaya Naberezhnaya, 13, St. Petersburg, \\ 197198, Russian Federation \\ ${ }^{2}$ St. Petersburg State Agrarian University, Peterburgskoeshosse, 2, St. Petersburg-Pushkin, 196601, \\ Russian Federation \\ ${ }^{3}$ Federal State Budgetary Institution North-West Centre of Interdisciplinary Researches of Problems \\ of Food Maintenance, Podbelskogo shosse, 7, St. Petersburg, 196608, Russian Federation \\ ${ }^{4}$ Peter the Great St. Petersburg Polytechnic University, Polytechnicheskaya, 29, St. Petersburg, \\ 195251, Russian Federation \\ ${ }^{5}$ Politecnoco di Milano, 32 Piazza Leonardo da Vinci, Milano, 20133, Italian Republic
}

\begin{abstract}
This study focuses on improving the technology for the preparation of geospatial information for land management design. The following hypothesis was the basis of the study: if the technology of geoecological assessment of the territory in the GIS environment is developed in the preparation of information for land management design, then its quality will increase, and as a result, the effectiveness of managerial decisions in the field of environmentally friendly land use will increase as well. The geoecological assessment of the territory is understood as the mathematical-cartographic, spatial, multi-parameter analysis of the auspiciousness of its agro-resource and geoecological conditions for sustainable production of plant agricultural products without disrupting the functions of life support (environmental and resource production). The developed technology can be used to solve the following problems: a) improving the land management system; b) improving control of land management; c) the formation of a database on the suitability of the territory for agricultural development, taking into account its sustainability; d) the territorial distribution of agricultural loads based on the geoecological situation. The advantage of the technology developed by the authors lies in the fact that a really working mechanism of geoecological assessment of the territory in the GIS environment is created when preparing information for land management design, which will allow to improve the quality of the developed design solutions and as a result will ensure the environmental safety of the functioning of natural and agricultural systems and the careful use of land resources.
\end{abstract}

\footnotetext{
* Corresponding author: coolhabit@yandex.ru
} 


\section{Introduction}

At the present stage of development of land management design, issues of its informational support, focused on taking into account the capabilities of the natural environment to produce agricultural products without disrupting the functions of resource and environmental reproduction, are becoming especially acute [1-5]. This is especially important in the face of increasing land degradation processes [6] and in the light of advancing of the technologies for soils hydrophysical and hydrological properties estimation for practical use in the land management [7-9].

However, the information support approaches currently used in land management design are not effective enough. It is evident from the fact that the vast majority of them do not allow the introduction of modern land management technologies in land management practice. The above mentioned leads to significant difficulties in establishing the legal regime and conditions for the rational use of land, as well as to the ineffective application of the economic mechanism to regulation of territorial relations.

This study is focused on the improvement of the technology for the preparation of geospatial information for land management design. A geographic information system acts as a tool that implements this technology, which allows one to process coordinate-linked information and present the results of its processing in a cartographic form. That is necessary when performing land surveying [10].

The following hypothesis was the basis of the study: if the technology of geoecological assessment of the territory in the GIS environment is developed in the preparation of information for land management design, then its quality will increase, and as a result, the effectiveness of managerial decisions in the field of environmentally friendly land use will increase as well.

\section{Materials and methods}

The studies $[1,2,11]$ show the need to improve information support for land management design. However, despite of this, the existing approach to the preparation of information for land management does not fully comply with modern requirements. This is related to the underestimation of the impact of agricultural production on the sustainability of the environment as well as to insufficient use for the preparation and presentation of geospatial information of a rich arsenal of geographic information systems. The geoecological assessment of the territory was used as the basis of the developed technology. The geoecological assessment of the territory is understood as the mathematical-cartographic, spatial, multi-parameter analysis of the auspiciousness of its agro-resource and geoecological conditions for sustainable production of plant agricultural products without disrupting the functions of life support (environmental and resource production).It should be noted that currently there is not only no common criteria, but also there is no generally accepted approach to the geoecological assessment of the territory in preparation of information for land management design.

\section{Results and discussion}

The technology developed by the authors consists of seven stages:

1. determination of indicators characterizing the auspiciousness of agro-resource and geoecological conditions of the territory for sustainable production of plant agricultural products; 
2. creation by means of GIS of electronic "factorial" maps for indicators characterizing the agro-resource conditions of the territory;

3. development of a qualimetric scale of the boundaries of the classes of integrated assessment of agro-resource conditions of the territory;

4. integrated assessment and mapping of agro-resource conditions of the territory;

5. creation by means of GIS of electronic "factorial" maps for indicators characterizing the geoecological conditions of the territory;

6. development of a qualimetric scale of the boundaries of the classes of integrated assessment of the geoecological conditions of the territory;

7. integrated assessment and mapping of geoecological conditions of the territory.

Let's briefly consider the contents of each of the above mentioned stages using the example of a model territory located in the Tosnensky district of the Leningrad region.

First stage. To determine the indicators characterizing the auspiciousness of agroresource and geoecological conditions of the territory, an information model is created. The idea lies in formalizing the information necessary and sufficient for the implementation of the geoecological assessment procedure at the level of conceptual representation. In the process of creating an information model, four directories are developed of:

1. rules of geoecological assessment;

2. operations implementing the geoecological assessment procedure;

3. data necessary to perform operations;

4. relationships between operations and data.

A generalized information model is formed based on these directories. In our case, in accordance with the constructed information model, the auspiciousness of the territory for the production of plant agricultural products depends on the auspiciousness of agricultural and geoecological conditions.

The auspiciousness of agro-resource conditions are characterized by:

1) potential reflecting the influence of climatic factors on the production of plant agricultural products;

2) soil tolerance, reflecting the productivity of the soil cover;

The auspiciousness of geoecological conditions are characterized by:

1) ecological and geochemical resistance of soils to acidification that reflects the ability of soils to withstand acid influences;

2) soil leachability that reflects soil resistance to erosion processes;

3) ecosystem diversity of the territory that reflects the stability of the environment to agricultural loads;

4) density of the hydrographic network that reflects the stability of the territory to the removal of nutrients from agricultural land;

5) level of groundwater that reflects the resistance of the territory to waterlogging;

6) erosion potential of the relief, reflecting the resistance of the territory to erosion soils washout.

Second stage. At this stage, two "factorial" maps are being created: agroclimatic potential and soil tolerance. Wherein, a "factorial" map is a graphic model built in a GIS environment, that is needed to display spatially-linked information about the degree of manifestation of the studied indicator within the investigated area.

The following dependencies were used to create a "factor" map of agroclimatic potential:

$$
\begin{gathered}
\mathrm{A} P_{k}=\left[\left(\sum t>10^{\circ}\right) \cdot(\mathrm{HC}-\mathrm{p}) /(\mathrm{CC}+100)\right] . \\
\mathrm{HC}=\mathrm{R} / \mathrm{E}
\end{gathered}
$$




$$
\mathrm{C} C_{k}=\left[360 \cdot\left(t_{\max }^{\mathrm{O}}-t_{\min }^{\mathrm{O}}\right) /(\lambda+10)\right]
$$

where: APk is the agroclimatic potential of the $\mathrm{k}$-th calculation section, $\sum \mathrm{t}>10^{\circ}$ is the sum of temperatures over $10^{\circ} \mathrm{C}$ for the $\mathrm{k}$-th calculation section, $\mathrm{HC}$ is the humidification coefficient for the k-th calculation section, $\mathrm{p}$ is the amendment to $\mathrm{HC}, \mathrm{CC}$ is the climate continentality coefficient for the $\mathrm{k}$-th calculation section.

To create a "factorial" map of soil tolerance, a scale of qualitative characteristics of soils and lands developed for the territory of the Leningrad, Novgorod and Pskov regions [12] was used.

Third stage. The development of the qualimetric scale of the boundaries of the classes of integral indicators of the agro-resource conditions of the territory is based on the approaches used to create classification models. The rules for their construction are described in [13, 14].

To normalize the estimated values of the indicators, piecewise power functions are used: (4) for direct communication and (5) for feedback:

$$
\begin{gathered}
q_{i}=q_{i}\left(x_{i}\right)=\left\{\begin{array}{lr}
0, & x_{i} \leq \min _{i}, \\
\left(\frac{x_{i}-\min _{i}}{\max _{i}-\min _{i}}\right)^{\lambda}, & \min _{i}<x_{i} \leq \max _{i}, \\
1, & x_{i}>\max _{i}
\end{array}\right. \\
q_{i}=q_{i}\left(x_{i}\right)=\left\{\begin{array}{lr}
1, & x_{i} \leq \min _{i}, \\
\left(\frac{\max _{i}-x_{i}}{\max _{i}-\min _{i}}\right)^{\lambda}, & \min _{i}<x_{i} \leq \max _{i}, \\
0, & x_{i}>\max _{i} .
\end{array}\right.
\end{gathered}
$$

To determine the integral indicators of the normalized characteristics of the boundaries of the classes of agro-resource conditions of the territory, the dependence (6) is used:

$$
I=\frac{\sum_{i=1}^{m} q_{i}}{m},
$$

where: I is the integral indicator of the normalized characteristics of the class boundary at equilibrium values of the indicators; qi is the normalized estimated value of the i-th indicator; $m$ is the number of indicators involved in the assessment.

\begin{tabular}{|c|c|c|c|c|c|c|c|c|}
\hline \multirow{2}{*}{ Indicator } & \multicolumn{5}{|c|}{ Class of auspiciousness of agro-resource conditions } & \multirow{2}{*}{ Min } & \multirow{2}{*}{ Max } & \multirow{2}{*}{$\begin{array}{l}\text { Type of } \\
\text { con- } \\
\text { nection }\end{array}$} \\
\hline & 1 & 2 & 3 & 4 & 5 & & & \\
\hline \multirow{2}{*}{$\begin{array}{l}\text { Agroclimatic } \\
\text { potential, point }\end{array}$} & $6,4-6,7$ & $6,7-7,0$ & $7,0-7,3$ & $7,3-7,6$ & $7,6-7,9$ & \multirow{2}{*}{6,4} & \multirow{2}{*}{7,9} & \multirow{2}{*}{ Straight } \\
\hline & $0-0,2$ & $0,2-0,4$ & $0,4-0,6$ & $0,6-0,8$ & $0,8-1,0$ & & & \\
\hline \multirow{2}{*}{$\begin{array}{l}\text { Soil tolerance, } \\
\text { point }\end{array}$} & $0-30$ & $30-40$ & $40-60$ & $60-70$ & $70-90$ & \multirow{2}{*}{0} & \multirow{2}{*}{90} & \multirow{2}{*}{ Straight } \\
\hline & $0-0,33$ & $0,33-0,44$ & $0,44-0,67$ & $0,67-0,78$ & $0,78-1,0$ & & & \\
\hline \multirow{2}{*}{$\begin{array}{l}\text { Integral indicator } \\
\text { of agro-resource } \\
\text { conditions }\end{array}$} & $0-0,26$ & $0,26-0,42$ & $0,42-0,64$ & $0,64-0,79$ & $0,79-1,0$ & \multirow[b]{2}{*}{-} & \multirow[b]{2}{*}{ - } & \multirow[b]{2}{*}{ 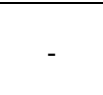 } \\
\hline & $\Delta=0,26$ & $\Delta=0,16$ & $\Delta=0,22$ & $\Delta=0,15$ & $\Delta=0,21$ & & & \\
\hline
\end{tabular}

The developed qualimetric scale of the boundaries of the classes of integral indicators of agro-resource conditions of the model territory is given in Table 1.

Table 1. Qualimetric scale of the boundaries of the classes of agro-resource conditions of the territory

Note: Class 1 - very unfavorable; class 2 - unfavorable; class 3 - medium favorable; class 4 - favorable; class 5 - very favorable. 
Fourth stage. An integrated assessment of the auspiciousness of agro-resource conditions of a territory begins with its division in the GIS environment into calculation areas $[15,16]$. The division procedure is carried out by summing up the agricultural land map with the "factorial" maps of the agroclimatic potential of the territory and soil tolerance. To summarize the maps, the topological overlay operation is used. The formed calculated areas represent homogeneous elementary areas within which the agroclimatic potential and soil difference have only one value. For each calculation area, the values of the indicators characterizing it are determined. Then, using dependencies (5), (6) and (7), integral indicators of the auspiciousness of agro-resource conditions of the territory are calculated, which are entered into the semantic database. After that, the plots that fall into one group of the auspiciousness of agro-resource conditions are combined and displayed with the adopted conditional sign. The map created according to the results of the assessment of the auspiciousness of agricultural conditions of the model territory for the production of plant agricultural products is shown in Fig. 1.

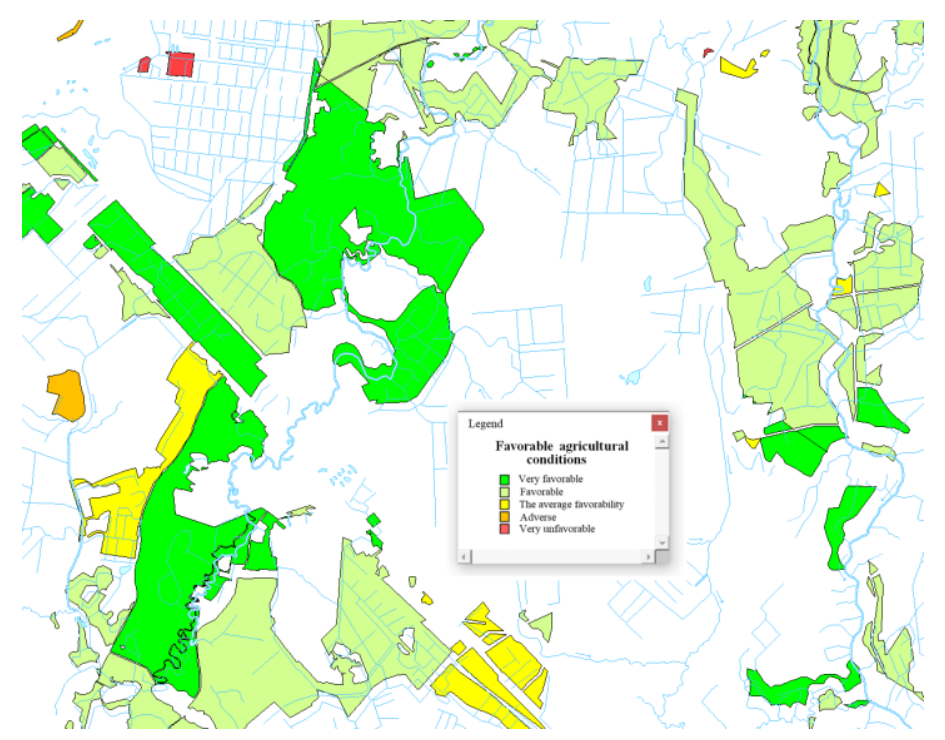

Fig. 1. The auspiciousness of agro-resource conditions of the model territory for the production of plant agricultural products.

Fifth stage. At this stage, six "factorial" maps are created: ecological and geochemical resistance of soils to acidification, soil erosion, ecosystem diversity, density of the hydrographic network, depth of groundwater, and erosion potential of the relief.

To create a "factorial" map of the ecological and geochemical resistance of soils to acidification, the following dependence was used [4]:

$$
u_{i k}=\left[\left(a_{i}+a l_{i}\right) /\left(o_{i}+g_{i}+o b_{i}\right)\right] /\left[\left(o_{i}+g_{i}+o b_{i}+k_{i}+c_{i}+o v_{i}\right) /\left(a_{i}+a l_{i}\right)\right] \text {. }
$$

where: ai is the influence of acid- and alkaline conditions of the i-th group of soils on their resistance to acidic influences; ali - the effect of amorphous $\mathrm{Fe}+\mathrm{Al}$ hydroxides on the resistance of the $\mathrm{i}$-th group of soils to acidic influences; oi is the influence of the thickness of the $\mathrm{O}+\mathrm{AO}$ horizons on the resistance of the $\mathrm{i}$-th group of soils to acid influences; gi is the effect of the thickness of horizon $\mathrm{A}$ on the resistance of the i-th group of soils to acid influences; obi is the effect of the amount of exchange bases in organic and humus horizons on the resistance of the i-th group of soils to acidic influences; ki is the effect of carbonates in the i-th soil group on its resistance to acidic effects; ci - the effect of exchangeable $\mathrm{Na}$ 
contained in the i-th soil group on its resistance to acidic influences; ovi - the effect of redox conditions on the resistance of the i-th group of soils to acidic influences.

To create a "factorial" map of soil erosion, the nomogram shown in [4] was used. The following relationship was used to create a "factorial" map of ecosystem diversity:

$$
\text { Is }=1-\sum \mathrm{S} 2 \mathrm{i} \text {, }
$$

where $\mathrm{Si}$ is the fraction of the area of the studied territory occupied by the i-th ecosystem.

The index values vary from 0 to 1 . If the index is zero, then the studied area contains only one ecosystem and, accordingly, there is no diversity. The index tends to one with an increase in the number of ecosystems and with an increase in the uniformity of their distribution. To create a "factorial" map of the hydrographic network density, the following dependence was used:

$$
G_{k}=\frac{V_{k}}{S_{k}},
$$

where Gk is the density of the hydrographic network of the k-th investigated area $(\mathrm{km} /$ $\mathrm{km} 2)$; Vk is the lengths of all surface watercourses of the k-th investigated area $(\mathrm{km})$; Sk is the area of the k-th investigated area $(\mathrm{km} 2)$. To create a "factorial" map of the depth of groundwater within the studied area, the materials of hydrogeological studies were used. The following dependencies were used to create a "factorial" map of the erosion potential of the relief [4]:

$$
\mathrm{E}_{R k}=22,1^{-p} \cdot L^{p} \cdot 18,62 \cdot \sin [\operatorname{arctg}(1 / 100 \cdot \alpha)] /\left(1+10^{0,53-0,15 L \alpha}+0,065\right) .
$$

where $\alpha$ is the slope, $\%$; $\mathrm{L}$ is the length of the streamline, $\mathrm{m}$. The parameter $\mathrm{p}$ is determined by the following relationship:

$$
p=0,2+2,067 \cdot\left(p_{0}-0,2\right) \cdot L^{-0,15} \cdot \mathrm{P}^{-0,45} .
$$

where $\mathrm{P}$ is the soil erodibility, $\mathrm{t} / \mathrm{ha}$; $\mathrm{p} 0$ - on slopes with a slope of $<1 \%$ it takes a value of $0.2 ; 1-3 \%-0.3 ; 3-5 \%-0.4 ;>5 \%-0.5$.

$$
\mathrm{k}=\sum_{j=1}^{m}\left[\left(\sum_{i=1}^{n} \mathrm{E}_{D i, j}^{\prime} \cdot \mathrm{P}_{i, j}^{\prime} / 10000\right) \cdot F_{i}\right] / 100
$$

where E'Di,j is the erosion potential of rainfall in the i-th development period of the $\mathrm{j}$-th group of crops; $\mathrm{P}^{\prime} \mathrm{i}, \mathrm{j}$ is the soil washout coefficient in the $\mathrm{i}$-th development period of the $\mathrm{j}$-th group of crops, $\%$; $\mathrm{Fi}$ is the sown area under the $\mathrm{j}$-th group of crops, ha; $\mathrm{j}$ - cultivated crop groups $j=1, m ; i$ - periods of cultivation of crop groups $i=1, n$.

The economic and ecological significance of the washout problem is obvious: the removal of nutrients and other agricultural chemicals out of the root zone of the soil by means of a downward water flux creates unproductive losses of mineral fertilizers, pesticides and land reclamation chemicals [17-20].

Sixth stage. The development of the qualimetric scale of the boundaries of the classes of integrated assessment of the geoecological conditions of the territory is carried out in the same way as the qualimetric scale of the boundaries of the classes of agro-resource conditions of the territory (stage three). 
The developed qualimetric scale of the boundaries of the classes of integral indicators of the geoecological conditions of the model territory is given in Table 2.

Table 2. Qualimetric scale of the boundaries of the classes of geoecological conditions of the territory

\begin{tabular}{|c|c|c|c|c|c|c|c|c|}
\hline \multirow{2}{*}{ Indicator } & \multicolumn{5}{|c|}{ Class of auspiciousness of geoecological conditions } & \multirow{2}{*}{ Min } & \multirow{2}{*}{ Max } & \multirow{2}{*}{$\begin{array}{c}\text { Type of } \\
\text { con-nection }\end{array}$} \\
\hline & 1 & 2 & 3 & 4 & 5 & & & \\
\hline $\begin{array}{l}\text { Ecological and } \\
\text { geochemical potential of } \\
\text { soils, point }\end{array}$ & $0-0,3$ & $0,3-0,5$ & $0,5-0,7$ & $0,7-0,9$ & $0,9-1,0$ & 0 & 5,0 & Straight \\
\hline \multirow[t]{2}{*}{ Soil washability, $\mathrm{t} / \mathrm{ha}$} & $4,5-4,0$ & $4,0-3,5$ & $3,5-3,0$ & $3,0-2,5$ & $2,5-2,0$ & \multirow{2}{*}{2,0} & \multirow{2}{*}{4,5} & \multirow{2}{*}{ Reverse } \\
\hline & $0-0,2$ & $0,2-0,4$ & $0,4-0,6$ & $0,6-0,8$ & $0,8-1,0$ & & & \\
\hline $\begin{array}{l}\text { Ecosystem diversity, } \\
\text { point }\end{array}$ & $1,0-0,8$ & $0,8-0,6$ & $0,6-0,5$ & $0,5-0,3$ & $0,3-0$ & 0 & 1,0 & Reverse \\
\hline $\begin{array}{l}\text { The density of the } \\
\text { hydrographic network, } \\
\mathrm{km} / \mathrm{km}^{2}\end{array}$ & $0-0,29$ & $0,29-0,47$ & $0,47-0,64$ & $0,64-0,82$ & $0,82-1,0$ & 0,1 & 1,8 & Reverse \\
\hline \multirow[t]{2}{*}{ Groundwater depth, $\mathrm{m}$} & $4,0-5,0$ & $5,0-6,0$ & $6,0-7,0$ & $7,0-8,0$ & $8,0-9,0$ & \multirow{2}{*}{4,0} & \multirow{2}{*}{9,0} & \multirow{2}{*}{ Straight } \\
\hline & $0-0,2$ & $0,2-0,4$ & $0,4-0,6$ & $0,6-0,8$ & $0,8-1,0$ & & & \\
\hline \multirow{2}{*}{$\begin{array}{l}\text { Erosion potential of the } \\
\text { relief, point }\end{array}$} & $1,8-1,5$ & $1,5-1,2$ & $1,2-0,9$ & $0,9-0,6$ & $0,6-0,2$ & \multirow{2}{*}{0,2} & \multirow{2}{*}{1,8} & \multirow{2}{*}{ Reverse } \\
\hline & $0-0,19$ & $0,19-0,38$ & $0,38-0,56$ & $0,56-0,75$ & $0,75-1,0$ & & & \\
\hline
\end{tabular}

Note: Class 1 - very unfavorable; Class 2 - unfavorable; Class 3 - medium favorable; Class 4 - favorable; Class 5 - very favorable.

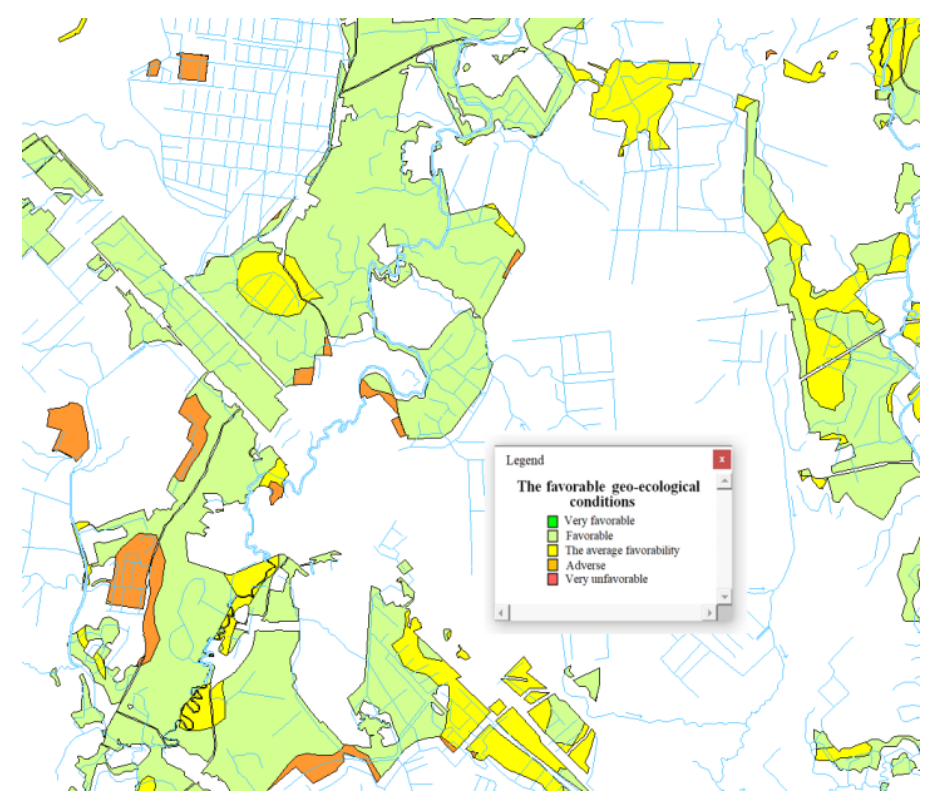

Fig. 2. Auspiciousness of geoecological conditions of the model territory for the production of plant agricultural products.

Seventh stage. The integrated assessment of auspiciousness of geoecological conditions of the territory is carried out in the same way as the integrated assessment of auspiciousness of agricultural-resource conditions of the territory (stage four). The map of auspiciousness of geoecological conditions of the model territory for the production of plant agricultural products, created according to the results of the assessment, is shown in Fig. 2. The approaches laid down in the basis of this study were developed on the basis of a generalization of the results of previous work, including: an integrated assessment of landscape stability when creating agricultural land of natural-agricultural systems [4], the use of GIS technologies in landscape zoning for suitability for agricultural development [16] and other. The developed technology can be used to solve the following problems: 1) improving 
the land management system; 3) improving control of land management; 4) the formation of a database on the suitability of the territory for agricultural development, taking into account its sustainability; 5) the territorial distribution of agricultural loads based on the geoecological situation. The results obtained by the authors are fully consistent with the hypothesis of the study.

Some papers of other authors are devoted to this problem as well. In our opinion, from the point of view of this study, the most interesting is the paper [10], which considered the original methodology for assessing the stability of natural landscapes to agricultural impact. It is based on the rationing of individual indicators of landscape stability with the subsequent summation of the points characterizing them, which, according to the author, makes it possible to determine the degree of their stability. The author uses sixteen indicators to assess the sustainability of landscapes, which are considered individually and independently of each other. In our opinion, despite the originality of this approach, it has significant drawbacks. The problem is that the assessment is based not on the modelling of the studied phenomena characterizing stability, but on the summation of individual indicators that are not interconnected, which does not fully reflect the geoecological processes taking place in the natural environment.

\section{Conclusion}

The advantage of the technology developed by the authors lies in the fact that a really working mechanism of geoecological assessment of the territory in the GIS environment is created when preparing information for land management design, which will allow improving the quality of the developed design solutions and, as a result, will ensure the environmental safety of the functioning of natural and agricultural systems and the careful use of land resources taking into account hydrological conditions of the territories and the hydrophysical properties of the soils with use of the agroecological mathematical modelling [21-26].

\section{References}

1. A.L. Zhelyaskov, A.P. Nesvat, Izvestiya Orenburgskogo gosudarstvennogo agrarnogo universiteta 1(45), 198-201 (2014) (rus)

2. N.V. Komov, A.S. Cheshev, Ekonomika i ekologiya territorial'nyh obrazovanij 1(4), 6-21 (2018)

3. V.B. Nepoklonov, I.A. Habarova, D.A. Habarov, V.A. Kiojbash, I.F. Abdugapirova, Mezhdunarodnyj sel'skohozyajstvennyj zhurnal 2, 12-15 (2018)

4. A.G. Osipov, Vestn. S.-Peterb. un-ta. Ser. 7. Geologiya. Geografiya 3, 150-162 (2016) (rus)

5. Land Administration in the UNECE Region. Development trends and main principles.Economic Commission for Europe. - United Nations, New York and Geneva (2005)

6. N.A. Kryukova, Zemleustrojstvo, kadastr i monitoring zemel 6 (30), 13-25 (2007) (rus)

7. V.V. Terleev, W. Mirschel, V.L. Badenko, I.Yu. Guseva, Eurasian Soil Science 50(4), 445-455 (2017)

8. A. Nikonorov, V. Terleev, S. Pavlov, I. Togo, Y. Volkova, T. Makarova, V. Garmanov, D. Shishov, W. Mirschel, Procedia Engineering 165, 1741-1747 (2016) 
9. V. Terleev, E. Petrovskaia, N. Sokolova, A. Dashkina, I. Guseva, V. Badenko, Y. Volkova, O. Skvortsova, O. Nikonova, S. Pavlov, A. Nikonorov, V. Garmanov, W. Mirschel, MATEC Web of Conferences 53, 01013 (2016)

10. I.V. Orlova, Landshaftno-agroekologicheskoe planirovanie territorii municipal'nogo rajona (Novosibirsk: Izd-vo SO RAN, 2014) (rus)

11. I.A. Habarova, D.A. Habarov, T.R. Altynbaev, A.A. Blyablin, S.Yu. Rodovnichenko, Mezhdunarodnyj zhurnal prikladnyh nauk i tekhnologij Integral 2, 49 (2018) (rus)

12. N.L. Blagovidov, Kachestvennaya ocenka zemel' $i$ ih racional'noe ispol'zovanie (L., 1962) (rus)

13. V.V. Dmitriev, A.N. Ogurcov, Vestnik Sankt-Peterburgskogo universiteta. Seriya 7. Geologiya. Geografiya 3, 88-103 (2013) (rus)

14. V.V. Dmitriev, A.N. Ogurcov, Vestnik Sankt-Peterburgskogo universiteta. Seriya 7. Geologiya. Geografiya 4, 114-130 (2014) (rus)

15. A.A. Nikiforova, Izvestiya Rossijskoj akademii nauk. Seriya geograficheskaya 1, 120-127 (2010) (rus)

16. A.G. Osipov, V.V. Garmanov, Sbornik nauchnyh trudov «Nauchnoe obespechenie razvitiya APK v usloviyah importozameshcheniya». - CH. II / SPbGAU. - SPb, 238243 (2018) (rus)

17. V. Terleev, E. Petrovskaia, A. Nikonorov, V. Badenko, Y. Volkova, S. Pavlov, N. Semenova, K. Moiseev, A. Topaj, W. Mirschel, MATEC Web of Conferences 73, 03001 (2016)

18. V.V. Terleev, W. Mirschel, U. Schindler, K.-O. Wenkel, International Agrophysics 24(4), 381-387 (2010)

19. R.A. Poluektov, V.V. Terleev, Russian Meteorology and Hydrology 12, 73-77 (2005)

20. V.V. Terleev, A.G. Topaj, W. Mirschel, Russian Meteorology and Hydrology 40(4), 278-285 (2015)

21. N. Arefiev, V. Badenko, A. Nikonorov, V. Terleev, Y. Volkova, Procedia Engineering 117(1), 20-25 (2015)

22. A. Nikonorov, S. Pavlov, V. Terleev, N Arefiev, V. Badenko, Y. Volkova, Procedia Engineering 117(1), 258-263 (2015)

23. A. Makarov, A. Mihailova, N. Arefiev, S. Pavlov, T. Chashchina, V. Terleev, V. Badenko, Procedia Engineering 117(1), 225-231 (2015)

24. O. Degtyareva, G. Degtyarev, I. Togo, V. Terleev, A. Nikonorov, Y. Volkova, Procedia Engineering 165, 1619-1628 (2016)

25. S. Medvedev, A. Topaj, V. Badenko, V. Terleev, IFIP Advances in Information and Communication Technology 448, 252-261 (2015)

26. V. Badenko, V. Terleev, A. Topaj, Applied Mechanics and Materials 635-637, 16881691 (2014) 